Journal of Food and Dairy Sciences

Journal homepage: www.jfds.mans.edu.eg

Available online at: www.jfds.journals.ekb.eg

\title{
Impact of Enzymatic Aqueous Extraction Mango Seed Oil on Physicochemical Properties and Oxidative Stability
}

\author{
Mehanni, A. E. *
}

Food Sci. Dep. Fac. of Agric. Sohag Univ., Sohag, Egypt.

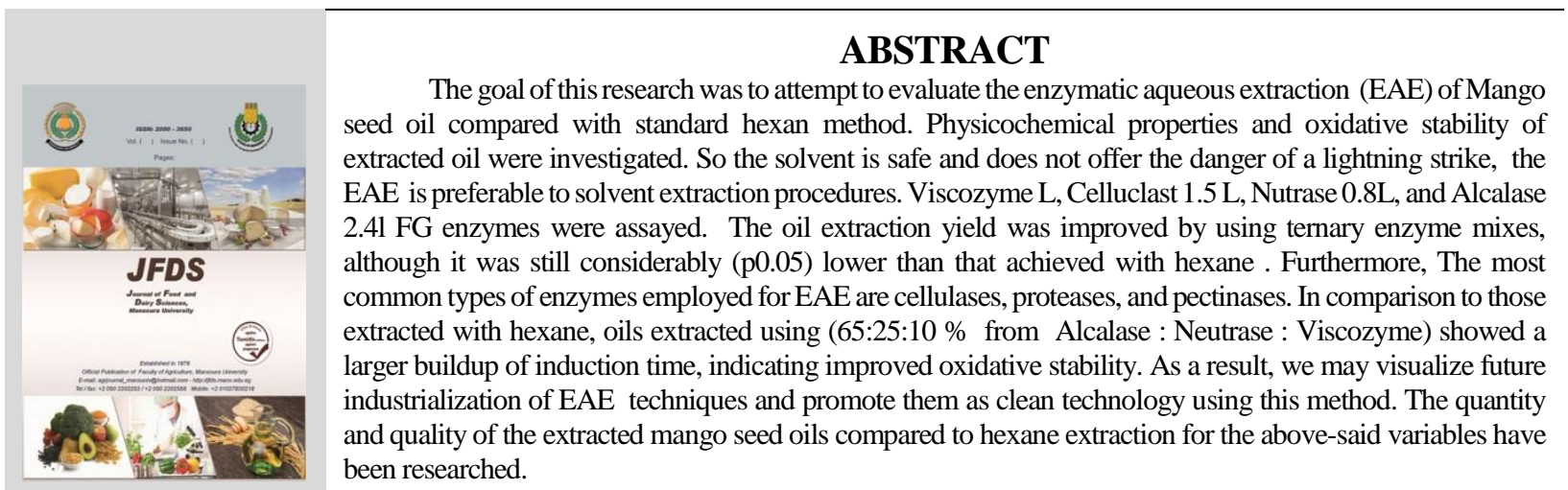

Keywords: Mango-seed oil; hexane; enzymatic aqueous ; oxidative stability

\section{INTRODUCTION}

Mango is the fruit of Mangifera indica, a tree that is native to Southeast Asia and Africa. Mango fruit ranked fifth in total world production among all main fruit crops, according to FAO (2004). According to Solis-Fuentes and Duran-de-Baza (2011), 28.5 MT tonnes of mango are produced and traded globally each year. Mangoes are mainly grown in over 103 countries, especially India, Mexico, Brazil, Philippines, Nigeria, Egypt, and Australia accounting for around 85 percent of global mango production (FAO, 2007; Vasanthaiah, Ravishankar, \& Mukunda, 2007). The mango plant grows well in tropical climates in Egypt, Thailand, India, China, and Florida. It has a sweet, yellow flesh and a large pit in the center. The pit is also called the kernel, seed, or stone. Mango oil is the extracted fat that comes from this pit. Mango oil contains mangiferin, a plant compound with antioxidant benefits. In some studies, a good source of mangiferin was found to inactivate collagenase and elastase, two enzymes involved in skin aging. It also may have benefits for dry skin, itchiness, irritation, cracking, and rashes. The oil can be extracted using high pressure, which physically presses the fat out of the seed Solis-Fuentes and Duran-de-Bazúa (2011). It can also be removed by solvent extraction, which uses various compounds to separate the oil. Any good oil extraction procedure must include hexane extraction. Using aqueous enzymatic medium, new techniques for extracting oil from vegetable oil seeds have been developed. Traditional procedures such as presses and organic solvents are no longer used within new bioprocesses. However, because of the wide range of cell wall and chemical characteristics of oil-rich plant materials (various amounts of cellulose, hemicelluloses, and pectin), establishing EAE procedures has proven difficult. In EAE, cellulases, proteases, and pectinases are the most widely utilised (Abdulkarim et al., 2006; Moreau et al., 2007). However, Recent advancements in enzyme manufacturing techniques could soon make the procedures more costeffective than hexane ( Mehanni et al., 2016). In this study, The oil taken during the grinding of mango seeds is known as mango oil. Mango oil is derived from the fruit's kernel or stone. When the oil is applied to the skin, it is semi-solid and melts. It is unfit for consumption since it contains almost 45 $\%$ saturated fat and a considerable level of unsaturated fat. Several drivers are contributing to the growth of the global mango seed oil and butter market. The major factors that fuel the market's growth are the growing awareness about the health benefits of mango fats and their rising use in the cosmetic and beauty industry. However, one of the main challenges is the increasing competition from other specialty oils. The worldwide mango seed oil and butter market is being guided by a range of reasons. The expanding awareness of the medical benefits of mango fats, as well as their increasing application in the cosmetic and aesthetic industry, are two important reasons supporting the market's rise. One of the most significant concerns, however, is the growing competition from other specialized oils (Solis-Fuentes and Duran-de-Bazúa (2011). When compared to other goods like cocoa butter, jojoba oil, coconut oil, and others, mango oil and butter has a higher price (Momeny et al., 2012). The present study aimed to evaluated enzymatic aqueous extraction protocol for maximum oil yield regarding the type of enzymes mixtures, viz. hexane extraction, and physiochemical properties and stability.

\section{Materials}

\section{MATERIALS AND METHODS}

Seed oil samples: Mango seeds Mangifera indica were employed as the study's samples. The seeds were collocated 
from Sohag market, Egypt. The seeds were put into PE bags (each : $2-5 \mathrm{~kg}$ seeds) and kept frozen at $-20 \mathrm{oC}$ until they were analysed.

Enzymes: Viscozyme L, Celluclast 1.5L, Nutrase 0.8L, and Alcalase $2.41 \mathrm{FG}$ used in this study. Novozyme A/S, Krogshoejvej36, Dk-2880 Bagsvaerd, Denmark, generously provided these enzymes. These enzymes were chosen due to their efficiency as extraction enzymes and their wide use in the food industry (Mehanni et al., 2016). The marketing and chemical identities of the enzymes studied, as well as their ideal activity parameters, are listed in Table 1.

Table 1. The market and chemical names of the studied enzymes, and ideal activity parameters.

\begin{tabular}{|c|c|c|c|c|}
\hline \multirow{2}{*}{ Code } & \multicolumn{2}{|c|}{ Enzymes } & \multicolumn{2}{|c|}{ Ideal activity * } \\
\hline & Market name & Composition & $\mathbf{T}\left({ }^{\circ} \mathrm{C}\right)$ & pH \\
\hline A & Alcalase $2.5 \mathrm{~L}$ & Protease & 55 & $6-8.5$ \\
\hline B & Celluclast1.5L & Cellulose/xylanase & 55 & $5-7$ \\
\hline $\mathrm{C}$ & Viscozyme L & $\begin{array}{l}\text { Pectinase/ xylanase } \\
\text { /Bglucanase /cellulase }\end{array}$ & 50 & $4.5-7$ \\
\hline D & Neutrase $0.8 \mathrm{~L}$ & Protease & 50 & $5-7$ \\
\hline
\end{tabular}

Solvents:N-hexane, $99.9 \%$ pure, with a boiling degree of 70 ${ }^{\circ} \mathrm{C}$ (for $95 \%$ dispersion) and sp. gr. $0.665 / 20^{\circ} \mathrm{C}$, utilised as a solvent. All chemicals were purchased from Sigma Aldrich (USA). Also, El-Nasr Company for Pharmaceutical Chemicals, Egypt, provided additional chemicals that were either analytical grade or of the highest quality.

\section{Mango seed oil extraction:}

\section{Hexane Extraction:}

The solvent extraction method based on the Soxhlet method is the most used method for obtaining vegetable oil. For the oil to be delivered from the solid matrix to a fluid medium, crushed mango seeds are placed in a packed bed that is in contact with pure solvent.

A Soxhlet separator with a $0.5 \mathrm{~L}$ round bottom flask and a condenser was used to extract the ground material $(25 \mathrm{~g})$. After extraction, hexane was distilled out under vacuum using a rotary evaporator (Eyela, Japan) at $45^{\circ} \mathrm{C}$, and the extracted oil was kept refrigerated $\left(4{ }^{\circ} \mathrm{C}\right)$ until used for further investigation (Latif and Anwar, 2009 and Mehanni et al., 2016).

\section{Enzymatic aqueous extraction:}

Aqueous enzymatic extraction (AEE) is an efficient and clean procedure that extracts oil and protein from most oilseeds at the same time. The enzymes utilised for each oilseed are chosen based on the differences in their structure. The enzymatic aqueous extraction was performance after removed the endocarps (pits) of Mango seeds. $15 \mathrm{~g}$ of powdered seeds modified incorporated into separate $250 \mathrm{ml}$ flasks, and $150 \mathrm{ml}$ of d.w. was a 1:10 (w/v) ratio, and it is regarded to be the ideal level for the oil extraction process (Domingues et al., 1995, and Meahnni et al., 2014).

As shown in figure 1, the samples were lightly boil for 5 minutes before becoming cooled to room temperature in an ice water bath. Thereafter, the collected supernatant was mixed with 2.0 percent enzyme and incubated under optimal circumstances.

According to Puangsri et al., (2005) the $\mathrm{pH}$ and temperatures were changed overnight to the ideal activity parameters for each enzyme process in Table 1 .
Miscellaneous was gathered and sifted. Anhydrous sodium sulphate was used to dry the crude oil.

Table 2. Formulation of enzyme mixtures

\begin{tabular}{|c|c|}
\hline $\begin{array}{l}\text { Types of ternary enzyme mixtures } \\
(65 / 25 / 10 \text { percent } w / w)^{*}\end{array}$ & Code \\
\hline $\begin{array}{l}\text { A: Alcalase 2.5L / B: Celluclast 1.5L / C: } \\
\text { Viscozyme L }\end{array}$ & $\mathrm{A} / \mathrm{B} / \mathrm{C}$ \\
\hline $\begin{array}{l}\text { A: Alcalase } 2.5 \mathrm{~L} / \mathrm{B} \text { : Celluclast 1.5L / } \\
\text { D:Neutrase 0.8L }\end{array}$ & $\mathrm{A} / \mathrm{B} / \mathrm{D}$ \\
\hline $\begin{array}{l}\text { A: Alcalase 2.5L / C: Viscozyme L/ } \\
\text { D:Neutrase 0.8L }\end{array}$ & $\mathrm{A} / \mathrm{C} / \mathrm{D}$ \\
\hline $\begin{array}{l}\text { A: Alcalase 2.5L / C: Viscozyme L/ B: } \\
\text { Celluclast 1.5L }\end{array}$ & $\mathrm{A} / \mathrm{C} / \mathrm{B}$ \\
\hline $\begin{array}{l}\text { A: Alcalase 2.5L / D:Neutrase 0.8L / B: } \\
\text { Celluclast 1.5L }\end{array}$ & $\mathrm{A} / \mathrm{D} / \mathrm{B}$ \\
\hline $\begin{array}{l}\text { A: Alcalase 2.5L / D:Neutrase 0.8L / C: } \\
\text { Viscozyme L }\end{array}$ & $\mathrm{A} / \mathrm{D} / \mathrm{C}$ \\
\hline \multicolumn{2}{|c|}{ Where: Ratios of enzyme mixtures adopted from (Mehanni, 2010). } \\
\hline $\begin{array}{r}\text { The amount of oil recovered v } \\
\% \text { The recover of oil }=\text { (Total oil ma } \\
\text { technique/ma } \\
\text { aqueous-enzy } \\
100 .\end{array}$ & $\begin{array}{l}\text { oximated as: } \\
\text { acted by hexan } \\
\text { l extracted by } \\
\text { technique) } \times\end{array}$ \\
\hline
\end{tabular}

Analytical methods:

Proximate analysis: According to the AOAC (1995), moisture, ash, crude fibre, and crude fat were measured. the nitrogen ratio was measured (AACC, 1999) according to the microKjeldahl method.

Physicochemical properties of Mango seed oil under investigation:

Color: Color Wesson methods were used to measure the colour of oil samples, which were calibrated using Lovibond glasses (Tintometer LTD, Wiles, England). According to the AOCS Official Methods (1998), a one-inch colour cell was employed. A method consistently used to evaluate and regulate the color of the studied oils was followed. The Tintometer uses a series of gradient red-, yellow-, blue-, and neutral-colored glasses. It is arranged with two adjacent fields of view, seen through the viewing tube, so that the product in the sample field and a white reflective surface in the comparison field are observed side by side, suitably illuminated. Red, yellow, blue, and neutral-colored glasses are used in the Tintometer. It's set up with two adjacent fields of view, both visible through the viewing tube, so that the product in the sample field and a white reflecting surface in the comparison field may be seen side by side, both adequately lighted.

Refractive index $(R I)$ : The bending of a ray of light as it passes through one medium and into another is measured by RI.

As a basis, the refractive index was determined using the approach as AOCS (1998). The results were adjusted at $25 \mathrm{oC}$ for vegetable oils using an automatic refractometer.

Acid value $(\boldsymbol{A V})$ : Acid value of the samples under investigation was studied in accordance with the AOCS (1998) and Salah and Nofal (2021). It was estimated as a percentage of free fatty acids as oleic acid.

Iodine value (IV) : The IV was estimated according to the method described by AOCS (1998). However, the IV was calculated as the amount of $I_{2}$ needed to saturate $100 \mathrm{~g}$ of oil. 


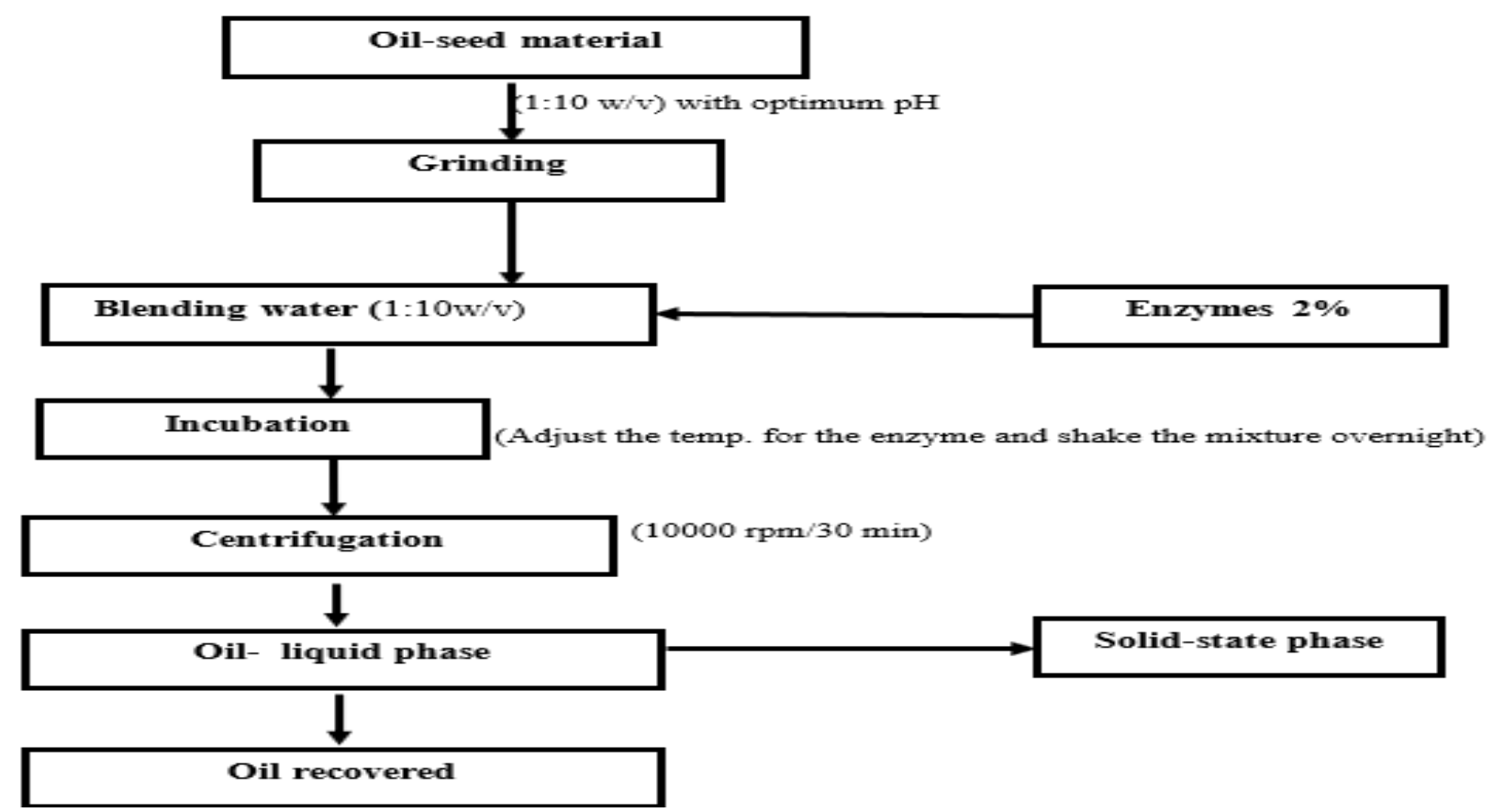

Fig. 1. The aqueous enzymatic oil extraction process is depicted in this diagram adapted from (Mehanni, 2010 and Mehanni, et al. 2016).

Peroxide Value (PV): PV is one of the most widely used quality measures to detect oxidation process and control oil quality, hence it's critical for edible oils. The AOAC (2000) and Endo (2018) were used to test this attribute. The PV was calculated in meqs. per $\mathrm{kg}$ of fat. The PV, on either hand, is the proportion of active oxygen peroxide in $1 \mathrm{~kg}$ of oil that can be released under the conditions studied. To dissolve the oil, $30 \mathrm{ml}$ of acetic acid-chloroform (3/2, v/v) was added to 5 $\mathrm{g}(0.05 \mathrm{~g})$ of the researcher analyzes in a flask. $0.5 \mathrm{ml}$ of a saturating KI ( $5 \mathrm{~g} / 5 \mathrm{ml}$ water) solution was added and stirred for $1 \mathrm{~min}$. before being placed in a light-protected bottle. After adding water $(30 \mathrm{ml})$ and a few droplets of starch solution, the released iodine is determined by titration with agitating of thiosulfate $0.02 \mathrm{~N}$.

Rancimat method: High temps $(50-150 \mathrm{oC})$ and vigorous agitation are employed in the Rancimat experiment to assess the oxidation stability of oils in a relatively short time, transforming the nature of the oxidisation. The Metrohm Rancimat 679 (Metrohm Ltd., Herisau, Switzerland) is used repeat the lab experiment as directed by Taskins et al., (1999). The following process was carried out after putting $5.0 \mathrm{~g}$ of each sample into each of the six react tubes. The Metrohm Rancimat (ARC, Egypt) was switched on until the oil batch temperature exceeds 120 degrees $\mathrm{C}$. Then, at a $20 \mathrm{Lh}-1$ air flow rate, $60 \mathrm{ml}$ of D.W. was placed into each of the 6 conductivity cells. The temperature was checked to make sure it remained constant. After the supply air was attached to the tubes holding the oil samples, the chart writer was started. The test ran on its own until the conductance reached its maximum level, at which moment the induction period was recorded. The oxidative stability index was calculated using the turning point of a computer-generated plot of DW conductivity vs time, as described in the AOCS (1998) and Mehanni, et al., (2016).

\section{Fatty acids composition:}

Fatty acid methyl esters preparation: Using hexane solution BF3 in methane, the FAs of the standard and samples were converted to methyl ester, according to Ackman (1998) and Mehanni et al., (2016). Fatty acids, on the other hand, catalysed esterification procedures in methanol utilising BF3 was based by Christie (1992). The material was immersed in hexane and a BF3 solution in methanol at a concentration of $12 \%$. The subsequent methylic esterification took $70 \mathrm{~min}$ at $100{ }^{\circ} \mathrm{C}$ using the boron trifluoride methanol complex BF3methanol.

Fatty acid methyl esters (FAMEs) were extracted in hexane. Before GC analysis, the sample was vortexed for 15 $\mathrm{sec}$ at room temperature.

Fatty acid identification: A GLC Shimadzo 2010 was used to evaluate fatty acid methyl esters and reference samples. The flame Ionization detected (F.I.D.) kind of GLC was utilised. The fatty acids methyl esters (FAME) were investigated using a GC Shimadzu-2010 (Japan) equipped with a flame ionisation detector and an automatic injection mechanism (AOC-2010i). The analysis was performed using a capillary column (CA, USA) with $\mathrm{H}_{2}$ as the carrier gas and $\mathrm{N}_{2}$ as the make-up gas. The oven was configured with the following temp regime: start column temp $51^{\circ} \mathrm{C}$ for $1 \mathrm{~min}$, then a 4-level rise in temperature from $170{ }^{\circ} \mathrm{C}$ to $240{ }^{\circ} \mathrm{C}$ until the procedure was completed. Lastly, the relative retention time of each peak was compared to that of standard samples to determine fatty acids peaks.

\section{Statistical analysis:}

All measurements were made in triplicate, and data was collected using independent $\mathrm{t}$ - test. The ANOVA technique was used to perform independent $t$ - test.

The SPSS statistics software was used to conduct the statistical analysis. Multivariate analysis of variance tests showed that there were substantial disparities in the means. 
Statistical significance was defined as a $\mathrm{P}$ value of less than 0.05 .

\section{RESULTS AND DISCUSSION}

Chemical composition: Table 3 shows the chemical analysis of mango seeds from an Egyptian wild provenance, as well as literature values for identical mango seeds. The results of this study are presented as the mean SD of three separate seeds, each examined in triplicate. Table 1: illustrates the proximate chemical composition of Mango seed samples. Moisture, ash, crude fiber, crude protein and crude fat were were $6.29 \%$, $2.15 \%, 2.32 \%, 6.34 \%$ and $11.19 \%$, respectively. Carbohydrates were calculated by difference. The findings are consistent with those of Nzikou et al (2010). Variability in chracteristics yield could be attributed to differences in plant variety, cultivation climate, ripening stage, seed harvaest time, and testing exatraxtion.

Table 3. The chemical composition of Mango seed.

\begin{tabular}{lc}
\hline \multicolumn{1}{c}{ Property $(\%)^{*}$} & $\begin{array}{c}\text { Mango seed g/100g } \\
\text { samples *** }\end{array}$ \\
\hline Moisture & $6.29 \pm 0.11^{\mathrm{a}}$ \\
Ash & $2.15 \pm 0.15^{\mathrm{a}}$ \\
Oil & $11.19 \pm 1.15^{\mathrm{ab}}$ \\
Crude Protein $(\mathrm{N} \times$ 6.25) & $6.34 \pm 0.19^{\mathrm{b}}$ \\
Fiber & $2.32 \pm 0.11^{\mathrm{c}}$ \\
Total carbohydrates $* *$ & $71.71 \pm 1.88^{\mathrm{a}}$ \\
\hline
\end{tabular}

(*) Wet weight; used to calculate the data.

(**) The difference was used to compute total carbohydrates.

(***) This table's figures are the average of three measurements; $\mathrm{M} \pm \mathrm{SD}$, Inside exactly same row, with the exactly same superscript symbols, the means are not statistically significant $(P>0.05)$.

\section{Oil extraction yield}

In comparison to aqueous enzymatic oil extraction(AEOE), hexane was used to separate the oils from mango seeds. Enzymatic processes resulted in a recovery of oil output, as seen in Table (4) ranging from 75.12 to 76.08 $\%$, respectively. hexane produced the highest oil yields in general. When the mango seed was extracted with hexane, the highest oil yield (11.19 percent DM) was obtained. Table (4) shows the oil and collection results for the combined ternary AEOE treatments. Although employing enzyme combinations improved oil extraction yields, they were still significantly lower (p0.05) than those achieved by hexane. Additionally, the findings clearly show that the various enzyme mixes used in this study were effective in improving oil yield to various extents. The variable compositions of the enzyme mixes investigated could possibly be to responsible for this impact. Rosenthal et al., (2001) and Mehanni et al., (2014) found that enzyme formulations with combined activity produce better outcomes. For the extraction of Mango seed oil, the most mixtures (A; Alcalase 2.5L, $65 \%$ : , C; Viscozyme L, 25\%, and D; Neutrase0.8L, 10\%.) were found to be best, giving $76.08 \%$ oil recovery. At the same time, only $75.12 \%$ of the oil was extracted (as $\mathrm{A}+\mathrm{B}+\mathrm{C}$; 65:25:10 w/w/w ; A = Alcalase 2.5L, B = Celluclast 1.5L, and C = Viscozyme L). According to McGlone et al. (1986), when polygalacturonase, amylase, and protease were employed in mix, the highest activity of coconut oil (80\%) was achieved. Abdulkarim et al. (2006) also claim that in extracting oil from Moringa oleifera seeds, AEOE proteases outperformed-amylase, pectinase, and cellulase, a between all enzymes, but at the other hand, proved to be considerably more efficient. AEOE carbohydrases, which include cellulase, arabinase, -glucanase, hemicellulase, and xylanase, were proved to be more accurate than protease or pectinase employed independently, according to Womeni et al., (2008). In rapeseed oil extraction, AEOE pectinase was more successful than cellulose, -glucanase, and xylanase when used alone, but it was less efficient when all four enzymes were combined (Zhang et al., 2007 and Xie, 2009). These findings suggest that processing mango seeds with ternary AEOE enzymes was more efficient and yielded more oil. The increase in oil extraction yield was due to several enzymes and their impacts on seed components such as protein, starch, and cellulose.

These findings are similar to those described by Hanmoungjai et al., (2002), Dzondo-Gadet et al., (2004), and Sawan et al., (2007).

Table 4. Different ternary enzyme mixture were used to extraction of Mang seed oil

\begin{tabular}{lc}
\hline Ternary mixtures* & Oil recovery $(\%) * *$ \\
\hline A/B/C $(65 / 25 / 10 w / w / w)$ & $75.12^{\mathrm{b}}$ \\
$\mathrm{A} / \mathrm{B} / \mathrm{D}(65 / 25 / 10 \mathrm{w} / \mathrm{w} / \mathrm{w})$ & $75.27^{\mathrm{b}}$ \\
$\mathrm{A} / \mathrm{C} / \mathrm{D}(65 / 25 / 10 \mathrm{w} / \mathrm{w} / \mathrm{w})$ & $76.08^{\mathrm{a}}$ \\
$\mathrm{A} / \mathrm{C} / \mathrm{B}(65 / 25 / 10 \mathrm{w} / \mathrm{w} / \mathrm{w})$ & $75.23^{\mathrm{d}}$ \\
$\mathrm{A} / \mathrm{D} / \mathrm{B}(65 / 25 / 10 \mathrm{w} / \mathrm{w} / \mathrm{w})$ & $75.34^{\mathrm{d}}$ \\
$\mathrm{A} / \mathrm{D} / \mathrm{C}(65 / 25 / 10 \mathrm{w} / \mathrm{w} / \mathrm{w})$ & $75.19^{\mathrm{c}}$ \\
\hline
\end{tabular}

(*) Commercial names are: $\mathrm{A}=$ Alcalase, $\mathrm{B}=$ Celluclast, $\mathrm{C}=$ Viscozyme, and $D=$ Neutrase. (Ternary EME) $(65 / 25 / 10 \mathrm{w} / \mathrm{w} / \mathrm{w})$.

$(* *)$ Each figure in this table is the mean of three measurements. Within the same row, the mean values for each oil group, followed by the same superscript letters, are not significantly different $(P>0.05)$.

\section{Physicochemical properties of extracted oil:}

The effects of six ternary EMs and hexane on the physico - chemical parameters of mango oils are represented in Table 5. When these enzymes were blended, however, they demonstrated no impact on the extracted oils' iodine value or refractive index when compared to the traditional hexane separation process. Oil quality is also assessed by free fatty acid and peroxide levels. These values were significantly lower when utilising this novel approach than when using hexane to extract the oils. This result of special interest agrees with previous studies (Mcginely, (1991); Ranalli et al., 1999 and Zhang et al., 2021).

Table 5. Effects of various ternary enzyme combinations and hexane on physicochemical properties of extracted mango seed oil

\begin{tabular}{|c|c|c|c|c|c|c|c|}
\hline \multirow[t]{2}{*}{ Characteristics** } & \multicolumn{6}{|c|}{$\begin{array}{c}\text { Mango seeds } \\
\text { Ternary enzyme formula } \\
\end{array}$} & \multirow{2}{*}{-Hexane } \\
\hline & $\mathbf{A} / \mathbf{B} / \mathbf{C}$ & $\mathbf{A} / \mathbf{B} / \mathbf{D}$ & $\mathrm{A} / \mathrm{C} / \mathrm{D}$ & $\mathrm{A} / \mathrm{C} / \mathrm{B}$ & $\mathbf{A} / \mathbf{D} / \mathbf{B}$ & $\overline{\mathrm{A} / \mathrm{D} / \mathrm{C}}$ & \\
\hline F.F.A. ( $\%$ as oleic acid ) & $4.16^{\mathrm{b}}$ & $4.13^{b}$ & 4. $15^{\mathrm{ab}}$ & $4.12^{\mathrm{b}}$ & $4.09^{\mathrm{ab}}$ & $3.99^{\mathrm{b}}$ & $3.75^{\mathrm{a}}$ \\
\hline $\begin{array}{l}\text { I.V. } \\
\text { PV(mea Peroxide/ka oil }\end{array}$ & $47.20^{\mathrm{a}}$ & $47.25^{\mathrm{a}}$ & $47.28^{\mathrm{a}}$ & $47.37^{\mathrm{a}}$ & $47.12^{\mathrm{a}}$ & $47.18^{\mathrm{a}}$ & $47.11^{\mathrm{a}}$ \\
\hline $\begin{array}{l}\text { P.V.(meq. Peroxide/kg oil). } \\
\text { Refractive index }\left(25^{\circ} \mathrm{C}\right)\end{array}$ & $1.28^{\mathrm{b}}$ & $1.29^{\mathrm{b}}$ & $1.27^{\mathrm{c}}$ & $1.26^{\mathrm{b}}$ & $1.25^{\mathrm{c}}$ & $1.30^{\mathrm{bc}}$ & $1.59^{\mathrm{a}}$ \\
\hline Total Lovibond colour & $1.5876^{\mathrm{a}}$ & $1.5872^{\mathrm{a}}$ & $1.5868^{\mathrm{a}}$ & $1.5874^{\mathrm{a}}$ & $1.5875^{\mathrm{a}}$ & $1.5873^{\mathrm{a}}$ & $1.5870^{\mathrm{a}}$ \\
\hline$(30 \mathrm{Y}+10 \mathrm{R})$ & $21.29^{\mathrm{b}}$ & $21.54^{\mathrm{b}}$ & $21.25^{\mathrm{b}}$ & $20.12^{\mathrm{b}}$ & $21.28^{\mathrm{b}}$ & $21.33^{\mathrm{b}}$ & $25.20^{\mathrm{a}}$ \\
\hline
\end{tabular}

(*) Enzymes commercial names are: $\mathbf{A}=$ Alcalase, $\mathbf{B}=$ Celluclast, $\mathbf{C}=$ Viscozyme, and $D=$ Neutrase (EME $(65 / 25 / 10 ; w / w / w)$.

$(* *)$ This table's figures are the average of three measurements; $\mathrm{M} \pm \mathrm{SD}$, Inside the same row, with the same superscript symbols, the means are not statistically significant $(P>0.05)$.

The reduced FFA and peroxide values of the oils extracted by aqueous enzyme mixtures reaction could be explained by mild extraction conditions in an aqueous medium at lower temperatures. However, as seen by the 
overall Lovibond colour parameter, the mixture of enzymes allows for a reduction in the level of phospholipids and colour compounds when used alone. Relatively mild extraction conditions in an aqueous medium at lower temperatures could explain the decreased FFA and peroxide values of the oils extracted by aqueous enzyme mixes process. When employed alone, the mixture of enzymes allows for a reduction in the level of phospholipids and colour compounds, as shown by the overall Lovibond colour factor. Fatty acid composition of the extracted Mango seed oils

Table 6 shows the fatty acid profiles extracted from mango seed oils using a variety of ternary enzyme mixtures. All of the analysis suggests the FAs composition of the oil obtained with enzyme combinations and hexane. Oleic acid was the most prevalent fatty acids, with concentrations ranging from 45.10 to $45.26 \%$ in enzyme-extracted samples and $45.12 \%$ in hexane-extracted oil. Stearic (37.59 to 37.69 $\%$ ), linoleic (8.68 to $8.98 \%$ ), and palmitic (5.36 to $5.46 \%$ ) FAs were also present in Mango oils.

Table 6. FA composition of mango oil extracted with and ternary enzyme formula compared hexane.

Mango seed oil
Ternary enzyme mixture TEM
$\mathrm{A} / \mathrm{B} / \mathrm{C} \mathrm{A} / \mathrm{B} / \mathrm{C} \mathrm{A} / \mathrm{B} / \mathrm{C} \mathrm{A} / \mathrm{B} / \mathrm{C} \mathrm{A} / \mathrm{B} / \mathrm{C} \mathrm{A} / \mathrm{B} / \mathrm{C}$ Hexane

\begin{tabular}{|c|c|c|c|c|c|c|c|}
\hline \multicolumn{8}{|c|}{ Saturated (SFA) } \\
\hline $\begin{array}{l}\text { Myristic } \\
\text { C } 14: 0\end{array}$ & $0.13^{\mathrm{a}}$ & $0.10^{\mathrm{a}}$ & $0.12^{\mathrm{a}}$ & $0.08^{\mathrm{a}}$ & $0.11^{\mathrm{a}}$ & $0.13^{\mathrm{a}}$ & $0.10^{\mathrm{a}}$ \\
\hline $\begin{array}{l}\text { Palmitic } \\
\mathrm{C}_{16: 0}\end{array}$ & $5.36^{\mathrm{a}}$ & $5.38^{\mathrm{a}}$ & $5.35^{\mathrm{a}}$ & $5.41^{\mathrm{a}}$ & $5.43^{\mathrm{a}}$ & $5.46^{\mathrm{a}}$ & $5.42^{\mathrm{a}}$ \\
\hline $\begin{array}{l}\text { Stearic } \\
\mathrm{C}_{18: 0}\end{array}$ & $37.62^{\mathrm{a}}$ & $37.57^{\mathrm{a}}$ & $37.59^{a}$ & $37.66^{\mathrm{a}}$ & $37.61^{\mathrm{a}}$ & $37.69^{a}$ & $37.50^{\mathrm{a}}$ \\
\hline $\begin{array}{l}\text { Total SFA } \\
\text { Unsaturated }\end{array}$ & $\begin{array}{l}43.12^{\mathrm{a}} \\
\text { d FA (UI }\end{array}$ & $\begin{array}{l}43.05^{\mathrm{a}} \\
\text { FA) }\end{array}$ & $43.06^{\mathrm{a}}$ & $43.15^{a}$ & $43.15^{\mathrm{a}}$ & $43.28^{a}$ & $43.02^{\mathrm{a}}$ \\
\hline $\begin{array}{l}\text { Oleic } \\
\mathrm{C}_{18: 1}\end{array}$ & $45.26^{\mathrm{a}}$ & $45.21^{\mathrm{a}}$ & $45.22^{\mathrm{a}}$ & $45.13^{a}$ & $45.10^{\mathrm{a}}$ & $45.18^{\mathrm{a}}$ & $45.12^{\mathrm{a}}$ \\
\hline $\begin{array}{l}\text { Linoleic } \\
\text { C } 18: 2 n-6^{-2}\end{array}$ & $8.93^{\mathrm{a}}$ & $8.89^{\mathrm{a}}$ & $8.88^{\mathrm{a}}$ & $8.68^{a}$ & $8.78^{a}$ & $8.98^{a}$ & $8.85^{\mathrm{a}}$ \\
\hline $\begin{array}{l}\text { Linolenic } \\
\text { C18:3n-3 }^{-3}\end{array}$ & $1.42^{\mathrm{a}}$ & $1.44^{\mathrm{a}}$ & $1.46^{\mathrm{a}}$ & $1.40^{\mathrm{a}}$ & $1.33^{\mathrm{a}}$ & $1.29^{\mathrm{a}}$ & $1.41^{\mathrm{a}}$ \\
\hline $\begin{array}{l}\text { Total } \\
\text { UFA }\end{array}$ & $55.61^{\mathrm{a}}$ & $55.54^{\mathrm{a}}$ & $55.56^{\mathrm{a}}$ & $55.21^{\mathrm{a}}$ & $55.21^{\mathrm{a}}$ & $55.45^{\mathrm{a}}$ & $55.38^{\mathrm{a}}$ \\
\hline $\begin{array}{l}\text { TUFA : } \\
\text { TSFA }\end{array}$ & $1.29^{\mathrm{a}}$ & $1.29^{\mathrm{a}}$ & $1.29^{\mathrm{a}}$ & $1.28^{\mathrm{a}}$ & $1.28^{\mathrm{a}}$ & $1.28^{\mathrm{a}}$ & $1.29^{\mathrm{a}}$ \\
\hline $\begin{array}{l}\mathrm{C}_{18: 2}: \\
\mathrm{C}_{18: 1}\end{array}$ & 0.16 & $0.16^{\mathrm{a}}$ & $0.16^{\mathrm{a}}$ & $0.16^{\mathrm{a}}$ & $0.15^{\mathrm{a}}$ & $0.14^{\mathrm{a}}$ & $0.16^{\mathrm{a}}$ \\
\hline
\end{tabular}

Oxidative stability of Mango seed oil: Based on the conductimetric assessment of volatile destruction of secondary oxidation products, the Rancimat test was used to assess the oxidative stability of crude Mango oil obtained using different separation process at a temperature of $120^{\circ} \mathrm{C}$. The results in Table 7 shows the values for the Rancimat induction period (IP). As evidenced by the short IP, the oil extracted using the hexane procedure exhibited the lowest total antioxidant activity $(5.51 \mathrm{~h})$. From the results it can be observed that the hexane-extracted oil had significantly (p0.05) lower oxidative stability than the enzyme-extracted oil. The oils' stability was regulated by a complex interplay among its endogenous elements, which related to the expiration date of the extracted crude oil, when the amount of unsaponifiable fraction was observed.

Table 7. The oxidative stability test (Induction period IP) of crude Mango oil

\begin{tabular}{lr}
\hline Extraction techniques & $\begin{array}{c}\text { IP } \\
\text { (h)* }\end{array}$ \\
\hline Hexane & $5.51^{\mathrm{a}}$ \\
AEM (65\%Alcalase/25\% Neutrase/10\%Viscozyme) & $8.10^{\mathrm{b}}$ \\
\hline * This table's numbers are the average of three readings. In about a single \\
row, the mean values for each oil group, are not statistically different (P> \\
$\begin{array}{l}\text { 0.05) when preceded by the same superscript symbols. } \\
\text { When evaluating enzyme-extracted oil to hexane }\end{array}$
\end{tabular}
trails, there was no notable change in the major FAs (P > 0.05). According to these findings, the type of enzyme used in the extraction had no effect on the FAs composition. There were no significant differences in the levels of the major FAs when the oils recovered using the combined ternary AEOE treatments were matched to each other or to the hexane extracted oil (p 0.05) (Dominguez et al., 1995 and 1996). The employment of enzymes in the extraction procedure in combined had no impact on the fatty acid composition of the oils, according to the same investigation. Other authors have described similar behavior (Dominguez et al., 1995; Sengupta and Bhattacharyya, 1996; Latif et al., 2007 and 2008; Mehanni et al., 2014).

\section{CONCLUSION}

The efficacy of four enzymes in oil extraction yield was improved by using ternary enzyme mixtures, although it was still considerably ( $\mathrm{P}$ 0.05)hexane produces the output that is lower. Mango seed was treated with a combination of $65 \%$ Alcalase, $25 \%$ Celluclast, and $10 \%$ Viscozyme , the maximum oil recovery was $68.26 \%$, followed by $65 \%$ Alcalase: $25 \%$ Viscozyme: $10 \%$ Neutrase.

The most latest blend was the best for extracting mango seed oil, with a recovery rate of $71.87 \%$. No improvements in the quality attributes and fattyc acids compositions of oils extracted by various ternary enzyme combinations. When incubated at 63 oC (Oven test), oils treated with $(65 \%$ Alcalase $125 \%$ Neutrase $110 \%$ Viscozyme) showed the lowest increase of PV, indicating superior oxidative stability than hexane treated. The stability of Mango oils extracted when using Rancimat test revealed that those extracted by using aqueousenzymatic method had a considerably (p0.05) longer IP than those extracted using hexane. The results of this investigation's economic assessment revealed that the enzyme-assisted AEP was significantly more expensive than the normal solventbased process. As used under optimal conditions, enzymes have been shown to greatly improve oil recovery when compared to aqueous extraction methods. Enzyme-extracted oils had decreased AV and colour intensity in general.. Furthermore, because the AEP takes place in an aqueous case, phospholipids and other water-soluble gums are removed from the oil, eliminating the need for degumming and lowering the overall refining cost. Enzymes are a healthier alternative to solvents, which are dangerous and difficult to dispose of after usage. This enzyme will be valuable in assessing the future viability of industrial applications. As a result, this procedure aids in the future industrial development of enzymatic aqueous extraction procedures as a green technology. 


\section{REFERENCES}

ABDULKARIM, S.M.; LAI, O.M., MUHAMMED, S.K.S., LONG, K. AND GHAZALI, H.M. (2006). Use of enzymes to enhance oil recovery during aqueous extraction of Moringa Olefera seed oil. J. of Food Lipid. 13:113 - 130.

ACKMAN, R.G. (1983). Chemical composition of Rapeseed oil. In: High and low erucic acid rapeseed oils, production, usage, chemistry and toxicological evaluation. pp. 85-129. KRAMER, J.K.G., SAUER, F.D., AND PIGDEN, W.J. (EDITORS) ACADEMIC PRESS. NEW YORK.

AOAC (2000). Official Methods of Analysis. Association of Official Analytical Chemists $\left(17^{\text {th }}\right.$ ed.)Washington, D.C.

AOCS (1998). Official and Tentative Methods of the American Oil Chemists Society $\left(5^{\text {th }}\right.$ ed.). American Oil Chemists Society, 35 East Waker Drive, Chicago, Illinois, USA.

CHRISTIE, W.W. (1992). Preparation of fatty acid methyl esters. Inform 3, $1031-1034$.

DOMINGUEZ, H.; NUNEZ, M. J. AND LEMA, J. M. (1995). Enzyme-assisted hexane extraction of soy bean oil. Food Chem. 54: 223-231.

DOMÍNGUEZ, H.; SINERIO, J, NÚNËZ, M. J. AND LEMA, J. M. (1996). Enzymatic treatment of sunflower kernels before oil extraction. Food Research Int. 28 (6):537-545.

DZONDO-GADET, M.; NZIKOU, J.M.; KIMBONGUILA, A.; LINDER, M. AND DESOBRY, S. ( 2004). Solvent and enzymatic extraction of Safou and Kolo oils. Eur. J. Lipid Sci. Technol. 106: 289 - 293.

Endo Y. (2018) Analytical Methods to Evaluate the Quality of Edible Fats and Oils: The JOCS Standard Methods for Analysis of Fats, Oils and Related Materials (2013) and Advanced Methods. J Oleo Sci. 2018 Jan 1;67(1):1-10. doi: 10.5650/jos.ess17130. Epub 2017 Dec 14. PMID: 29238025.

extracted oil. Journal of Food Biochemistry Volume 41, Issue $2,1745-4514$.

FAO, (2004) Oilseeds, Oils and Oilmeals. www. Fao.org. FAO, (2007) Oilseeds, Oils and Oilmeals. www. Fao.org.

HANMOUNGJAI, P.; PYLE, D.L. AND NIRANJAN, K. (2002). Enzyme-assisted water -extraction of oil and protein from rice bran. J. Chem. Technol. Biotechnol. 77:771-776.

LATIF, S. AND ANWAR, F. (2009). Physicochemical studies of hemp (Cannabis sativa) seed oil using enzyme-assisted cold-pressing, Euro. J. of Lipid Sci. and Technol., 111 (10): 1042 - 1048

LATIF, S.; ANWAR, F. AND ASHRAF, M.(2007). Characterization of enzyme-assisted cold-pressed cottonseed oil. Journal of Food Lipids 14 (4) 424- 436.

LATIF, S.; DIOSADY, L.L. AND ANWAR, F. (2008). Enzyme-assisted aqueous extraction of oil and protein from canola (Brassica napus L.) seeds. Euro. J. of Lipid Sci. and Techn. 110: 887-892.

MCGINELY, L. (1991). Quality Control for Processing and Processed Fats in Analysis of Oilseeds, Fats and fatty Foods. p. 480-481. J. B. ROSSELL \& J. L. R. PRITCHARD (Eds.), Elsevier Science Publishers Ltd., New York, London.
MCGLONE, O. C., LOPEZ-MUNGUIA, C. AND CARTER, J.C. (1986). Coconut oil extraction by a new enzymatic processes. J. Food Sci. 519: 695-697.

MEHANNI, A.A.E., W.H. EL-REFFAEI, ARMINDO MELO, SUSANA CASAL AND ISABEL M.P.L.V.O.FERREIRA (2016). Enzymatic extraction of oil from Balanites aegyptiaca (desert date) kernel and comparison with solvent extracted oil. Journal of Food Biochemistry 41(2) 1:6

MEHANNI, A.E., (2010). Studies of some extraction conditions and their effect on characteristics and stability of some edible oils. Ph.D. Thesis, Minia University, Minia, Egypt.

MEHANNI, A.E., W.H. EL-REFFAEI, E.P. AKDOWA AND A.A. BOUBA.(2014) Enzyme aqueous extraction of moringa oleifera seed oils and their effect on physiochemical characteristics and stability. Riv. Ital. Sostanze Grasse. VOL. XCI - (3) LUGLIO/SETTEMBRE pp. $187-197$

Momeny, E.; Rahmati, S. and Ramli, N. (2012). Effect of Microwave Pretreatment on the Oil Yield of Mango Seeds for the Synthesis of a Cocoa Butter Substitute. J Food Process Technol. 3 (7): 1-7.

MOREAU, R.A., JOHNSTON, D.B., DICKEY, L.C.; PARRIS, N. AND HICKS, K.B. (2007). Aqueous Enzymatic Oil Extraction: A "Green" Bioprocess to Obtain Oil from Corn Germ and Other Oil-Rich Plant Materials. In: Industrial Application of Enzymes on Carbohydrate-Based Material, Chapter 8, pp 101120. ACS Symposium Series, Vol. 972.

NZIKOU, J.M., A.KIMBONGUILA , L. MATOS, B. LOUM-OUAMOU , N.P.G. PAMBOU-TOBI , C.B.NDANGUI, A.A.ABENA, T. SILOU, J.SCHER AND S.DESOBRY, (2010). Extraction and characteristics of seed kernel oil from mango (Mangifera indica). Research Journal of Environmental Earth Science. 2: 31-35.

PUANGSRI, T., ABDULKARIM, S.M., AND GHAZALI, H.M. (2005). Properties of Carica papaya L. (papaya) seed oil following extraction using solvent and aqueous enzymatic methods. J. of Food Lipid. 12:62 $-76$.

RANALLI, A., SGARAMELLA, A. AND SURRICCHIO, G., (1999). The new “cytolase O” enzyme processing aid improves quality and yields of virgin olive oil. Food Chem. 66, pp. 443-454.

ROSENTHAL, A., PYLE, D.L. AND NIRANJAN, K. (1996). Aqueous and Enzymatic Processes for Edible Oil Extraction, Enzyme Microb. Technol. 19:402420.

ROSENTHAL, A.; PYLE, D.L.; NIRANJAN, K.; GILMOUR, S. AND TRINCA, L. (2001). Combined effect of operational variables and enzyme activity aqueous enzymatic extraction of oil and protein from soybean. Enzyme and Microbial Technology 28: 499 -509 .

Salah WA, Nofal M. (2021) Review of some adulteration detection techniques of edible oils. J Sci Food Agric. 2021 Feb;101(3):811-819. doi: 10.1002/jsfa.10750. Epub 2020 Sep 24. PMID: 32833235. 
SAWAN, Z.M.; HAFEZ, S.A.; BASYONY, A.E. AND ALKASSASB, A.R. (2007). Cottonseed: protein, oil extraction yield, and oil properties as influenced by potassium fertilization and foliar application of zinc and phosphorus. GRASAS Y ACEITES 58(1):40-48.

SENGUPTA, R., AND BHATTACHARYYA, D. K. (1996). Enzymatic extraction of mustard seed and rice bran. J Am Oil Chem. Soc.73: 687-692.

SOLÍS-FUENTES, J. A., \& DURÁN-DE-BAZÚA, M. C. (2011). Mango (Mangifera indica L.) seed and its fats. In V. Preedy, R. R. Watson, \& V. B. Patel (Eds.), Nuts and Seeds in health and disease prevention (Chapter 88, pp. 741-748). San Diego: Academic Press.

steers fed forage-based diets. J. Anim. Sci. 84: 499 - 507.

TASKINS, J., LALAS, S., GERGIS, V., DOURTOGLOU, V. AND SPILIOTIS, V. (1999). Characterization of Moringa oleifera seed oil of Kenya. J. Agric. Food Chem.; 47: 4495 - 4499.

Vasanthaiah, H. K. N., Ravishankar, K. V., \& Mukunda, G. K. (2007). Mango, genome mapping and molecular breeding in plants. In C. Kole (Ed.), Fruits and Nuts (Vol. 4, pp. 303-323) Berlin: Springer-Verlag.
WOMENI, H. M.; NDJOUENKEU, R.; KAPSEU, C.; MBIAPO, F. T.; PARMENTIER, M. AND FANNI, J. (2008). Aqueous enzymatic oil extraction from Irvingia gabonensis seed kernels. European Journal of Lipid Science and Technology 110 (3) 232-238.

XIE, M. (2009). Aqueous enzymatic extraction of wheat germ oil. M.Sc. Thesis, Oklahoma State University, Oklahoma, USA.

ZHANG, N, LI Y, WEN S, SUN Y, CHEN J, GAO Y, SAGYMBEK A, YU X. (2021) Analytical methods for determining the peroxide value of edible oils: A mini-review. Food Chem. Oct 1; 358:129834. doi: 10.1016/j.foodchem.2021.129834.

ZHANG, S.; WANG, Z. AND XU, S. (2007). Optimization of the aqueous enzymatic extraction of rapeseed oil and protein hydrolysates. J. Am. Oil Chem. Soc. 84: $97-105$.

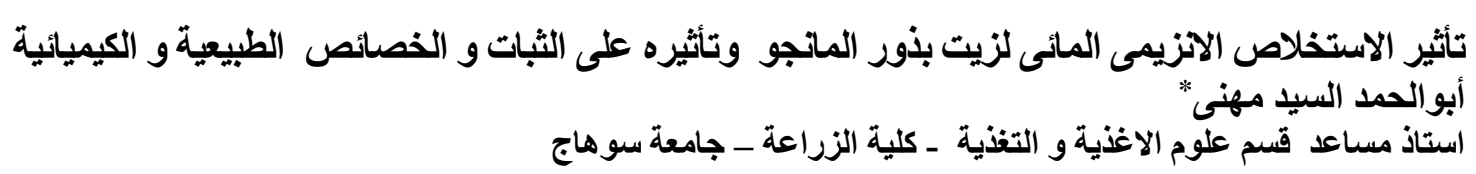

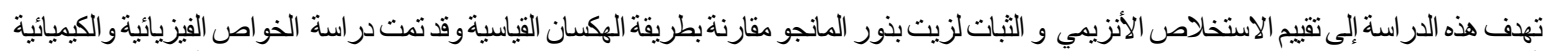

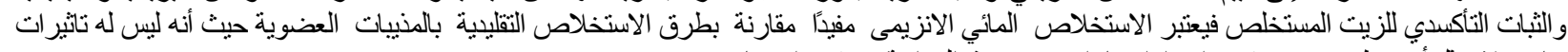

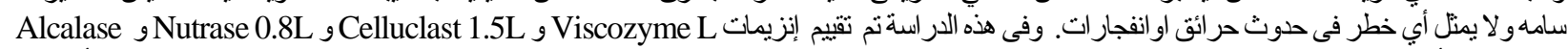

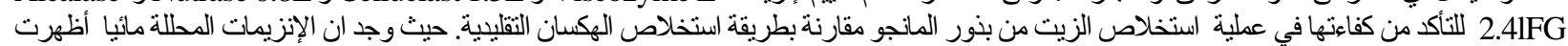
مستويات تحسن من الفاعلية في استخر اجلية الزيت. 